\title{
Erratum to: Impact of risks and threats on the region's food supply in the context of import substitution
}

\author{
Svetlana M. Kurbatova $^{1 *}$, Valery V. Vlasov ${ }^{2,3}$ and Larisa Yu. Aisner ${ }^{4}$ \\ ${ }^{1}$ Peter the Great Sankt-Petersburg Polytechnic university \\ ${ }^{2}$ Hamburg University of Technology (TUHH) \\ ${ }^{3}$ Saratov State Medical University \\ ${ }^{4}$ Krasnoyartsk State Agrarian University
}

Original article:

E3S Web of Conferences

Volume 161, 2020

International Conference on Efficient Production and Processing (ICEPP-2020)

DOI: $10.1051 / \mathrm{e} 3$ sconf/202016101089

Affiliations should be the following:

${ }^{1}$ Assoc. Prof., Candidate of Sciences, law Institute, Krasnoyarsk State Agrarian University, Krasnoyarsk, Russia

${ }^{2}$ Assoc. Prof., Candidate of Sciences, law Institute, Krasnoyarsk State Agrarian University, Krasnoyarsk, Russia

${ }^{3}$ Assoc. Prof., Candidate of Science, Siberian Law Institute of the Ministry of Internal Affairs of the Russian Federation, Krasnoyarsk, Russia

${ }^{4}$ Assoc. Prof., Candidate of Sciences, law Institute, Krasnoyarsk State Agrarian University, Krasnoyarsk, Russia 